\title{
Study of the Naphthenic Corrosion of AISI 316 and AISI 1020 Steels by Light, Scanning Electron and Atomic Force Microscopies (LM, SEM and AFM)
}

\author{
Débora V. Domingos, ${ }^{a}$ Fabrício C. Tozzi, Eliane V. Barros, ${ }^{a, b}$ Fernanda E. Pinto, ${ }^{b}$ \\ Cristina M. S. Sad, ${ }^{c}$ Paulo R. Filgueiras, ${ }^{b}$ Valdemar Lacerda Jr., ${ }^{*, b, c}$ Heloisa P. Dias, ${ }^{a, b}$ \\ Glória M. V. F. Aquije ${ }^{a, d}$ and Wanderson Romão $o^{* a, b, b}$ \\ anstituto Federal de Educação, Ciência e Tecnologia do Espírito Santo, \\ 29056-255 Vitória-ES, Brazil \\ ${ }^{b}$ Laboratório de Petroleômica e Forense, Departamento de Química, \\ Universidade Federal do Espírito Santo, 29075-910 Vitória-ES, Brazil \\ ${ }^{c}$ Laboratório de Pesquisa e Desenvolvimento de Metodologias para Análise de Petróleos (LabPetro), \\ Departamento de Química, Universidade Federal do Espírito Santo, 29075-910 Vitória-ES, Brazil \\ ${ }^{d}$ Instituto Federal de Educação, Ciência e Tecnologia do Espírito Santo, \\ 29106-010 Vila Velha-ES, Brazil
}

\begin{abstract}
Corrosion processes were evaluated for AISI 316 and AISI 1020 steels by scanning electron microscopy (SEM), atomic force microscopy (AFM) and light microscopy. Coupons were immersed in four crude oil samples with different total acid numbers (TANs) for 48 days at room temperature. The steels were also exposed to three blends (B1-B3), produced by quaternary mixtures of the oils, with lower TANs than their respective original oils. SEM micrographs showed pitting-type corrosion in most cases. AFM imaging showed drastic changes in the peak-to-peak values, topographic profiles and phase images of the AISI 1020 coupons exposed to all oils and blend B3 as compared to the unexposed steel. Defects were produced on the surface of almost all the samples exposed to naphthenic corrosion. Exposure to the oil blends reduced the extent of the naphthenic corrosion on the coupons, especially blends B1 and B2. The oil mixtures (blends) reduced corrosion.
\end{abstract}

Keywords: corrosion, SEM, AFM, blends, AISI 316, AISI 1020

\section{Introduction}

Naphthenic acids ${ }^{1}$ (NAs) are carboxylic acids with the general formula $\mathrm{R}-\left(\mathrm{CH}_{2}\right)_{\mathrm{n}}-\mathrm{COOH}$, where $\mathrm{R}$ corresponds to one or more cyclopentane or cyclohexane rings. ${ }^{2}$ Although NAs have been identified as major corrosive components in petroleum, this class of compounds represents only $3 \mathrm{wt} \%$ of the organic composition of crude oils. ${ }^{3}$

Estimating the concentration of NAs in oils is a daily task in the petroleum industry and is measured by a potentiometric titration method that uses potassium hydroxide $(\mathrm{KOH})$ solution. The result is the total acid number (TAN), defined as the amount of $\mathrm{KOH}$ (in $\mathrm{mg}$ ) required to neutralize all acidic species in $1 \mathrm{~g}$ of petroleum, including NAs. ${ }^{4}$

*e-mail: vljuniorqui@gmail.com; wandersonromao@gmail.com
Crude oils with TANs greater than $0.5 \mathrm{mg}$ of $\mathrm{KOH} \mathrm{g}^{-1}$ may have more issues with corrosion. ${ }^{5,6}$ Although this correlation is a commonly used gauge, in the literature, ${ }^{7}$ TAN has been described as an unreliable indicator due to significant differences in the reported corrosiveness of oils with the same TAN. Apart from TAN and NA structure, other variables can also directly influence the corrosion caused by typical crude oil, such as salinity, total sulfur content, temperature, mechanical stress and microbiological action., ${ }^{8,9}$

The industry has been investing in more corrosionresistant steels, such as AISI 316 stainless steel, as well as mixing heavy oils with light oils that have lower TANs (TAN $\left.<0.5 \mathrm{mg} \mathrm{KOH} \mathrm{g}^{-1}\right),{ }^{10}$ to reduce the corrosive effects on distillation towers, ducts, and metal materials involved throughout the entire oil processing chain. The oil mixture is called a blend; it can be tailored to reduce viscosity, 
which improves its fluidity in all refining steps, and also to reduce TAN and total sulfur contents, ${ }^{11}$ which are the primary causes of corrosion in oilseed plants. ${ }^{12}$

Several methods have been applied in the study of corrosion on metallic surfaces, such as electrochemical impedance spectroscopy (EIS), Raman and infrared (IR) spectroscopies, potentiostatic techniques, mass loss, light microscopy (LM) and scanning electron microscopy (SEM). Among these, LM and SEM have been widely used $^{13-15}$ because they allow structural, phase and morphological characterization of samples. ${ }^{16}$

Microscopic techniques such as SEM and atomic force microscopy (AFM) were employed by Marin et al. ${ }^{17}$ to investigate the morphology of $\mathrm{Al}_{2} \mathrm{O}_{3}$ and $\mathrm{TiO}_{2}$ coatings on the surface of AISI 316 steel in order to improve intrinsic corrosion resistance. Dias et al. ${ }^{18}$ also used SEM and AFM for monitoring naphthenic corrosion of AISI 1020 steel immersed in oils with different TANs (ca. 2.4 and $4.8 \mathrm{mg} \mathrm{KOH} \mathrm{g}^{-1}$ ) and subjected to thermal treatments for different exposure times. The AFM results showed that the surface of the steel immersed in the higher TAN oil was severely altered. ${ }^{18}$

SEM can be coupled with energy dispersive spectroscopy (EDS), which provides qualitative and semi-quantitative elemental compositions for the surfaces of materials. Because the analyses are relatively fast and the sample preparation is easy, SEM is useful in the study of surfaces. ${ }^{19}$ AFM is a high-resolution technique that provides in situ analyses of the surfaces of materials, ${ }^{15,20}$ measuring topographical, structural and elastic properties. Moreover, AFM has superior performance when compared to other microscopic techniques such as LM and SEM. ${ }^{21,22}$ AFM images have resolution in three dimensions, with magnifications on the order of millions, ${ }^{23}$ making it possible to quantify the surface roughness of materials. In this work, we combined SEM and AFM techniques to study the corrosion of AISI 316 and AISI 1020 steel caused by blends of oils and their respective crude oils.

\section{Experimental}

\section{Preparation and characterization of oils and mixtures}

Four crude oil samples were selected from a production field located in the sedimentary basin of the Brazilian coastal region: two offshore oils, designated P1 (American Petroleum Institute (API) 26.4, medium) and P2 (API 18.3, heavy); and two onshore oils, designated P3 (API 12.2, heavy) and P4 (API 19.6, heavy). These samples were analyzed in the Laboratory of Research and Development of Methodologies for Oil Analysis (LabPetro), Department of Chemistry (DQUI) at the Federal University of Espírito Santo (UFES).

Crude oil samples were collected in accordance with ASTM D5854. ${ }^{24}$ The characterization process for the oils began with the removal of free water (water not emulsified in the oil). Next, the oils were subjected to gravitational decantation for $1 \mathrm{~h} .{ }^{25}$ The water content in the water-oil emulsions was measured. ${ }^{26}$ Samples with a water content above $1 \%(\mathrm{v} / \mathrm{v})$ were dehydrated by adding $200 \mu \mathrm{L}$ of a commercial demulsifier at $60{ }^{\circ} \mathrm{C}$ and centrifuging at $1600 \mathrm{rpm}$ for $15 \mathrm{~min} .{ }^{27}$ These oils were designated as "dehydrated oils". After de-emulsification, the water content of the oils was measured again to verify that it was less than $1 \%(\mathrm{v} / \mathrm{v})$. Physicochemical properties of the oils were then characterized, such as API grade, ${ }^{28}$ density, ${ }^{29} \mathrm{TAN},{ }^{4}$ kinematic viscosity, ${ }^{30}$ and total sulfur. ${ }^{31}$ The physicochemical characterization of the oils and mixtures is summarized in Table 1.

Using the four crude oils selected, 68 blends (Table S1, Supplementary Information (SI) section) were prepared as

Table 1. Physicochemical characterization of the oils and their respective mixtures

\begin{tabular}{|c|c|c|c|c|c|c|c|}
\hline \multirow{2}{*}{ Physicochemical property } & \multicolumn{4}{|c|}{ Oil } & \multicolumn{3}{|c|}{ Blend } \\
\hline & $\mathrm{P} 1$ & $\mathrm{P} 2$ & P3 & $\mathrm{P} 4$ & B1 & B2 & B3 \\
\hline API degree \pm 1 & 26.4 & 18.3 & 12.2 & 19.6 & 22.5 & 30.0 & 20.4 \\
\hline Density at $20^{\circ} \mathrm{C} /\left(\mathrm{g} \mathrm{cm}^{-3}\right)$ & $\begin{array}{c}0.8916 \pm \\
0.0002\end{array}$ & $\begin{array}{c}0.9403 \pm \\
0.0002\end{array}$ & $\begin{array}{c}0.9801 \pm \\
0.0002\end{array}$ & $\begin{array}{c}0.9317 \pm \\
0.0002\end{array}$ & 0.91890 & 0.91600 & 0.93130 \\
\hline TAN / (mg KOH g $\left.{ }^{-1}\right)$ & $\begin{array}{c}0.3645 \pm \\
0.0013\end{array}$ & $\begin{array}{c}2.3056 \pm \\
0.0149\end{array}$ & $\begin{array}{c}2.4150 \pm \\
0.0320\end{array}$ & $\begin{array}{c}1.3356 \pm \\
0.0136\end{array}$ & 1.2156 & 1.0568 & 1.4620 \\
\hline Kinematic viscosity at $40{ }^{\circ} \mathrm{C} /\left(\mathrm{mm}^{2} \mathrm{~s}^{-1}\right)$ & $\begin{array}{c}45.020 \pm \\
0.026\end{array}$ & $\begin{array}{c}365.74 \pm \\
0.78\end{array}$ & $\begin{array}{c}15567 \pm \\
0\end{array}$ & $\begin{array}{c}204.40 \pm \\
0.27\end{array}$ & 119.53 & 113.905 & 259.645 \\
\hline Total sulfur / $(\% \mathrm{~m} / \mathrm{m})$ & $\begin{array}{c}0.15070 \pm \\
0.0001\end{array}$ & $\begin{array}{c}0.51901 \pm \\
0.0002\end{array}$ & $\begin{array}{c}0.49599 \pm \\
0.00209\end{array}$ & $\begin{array}{c}0.42028 \pm \\
0.00040\end{array}$ & 0.34733 & 0.31797 & 0.36856 \\
\hline
\end{tabular}

P: crude oil; B: blends; API: American Petroleum Institute; TAN: total acid number. 
Table 2. Concentrations of the oils P1, P2, P3 and P4 used for the production of three blends

\begin{tabular}{lcccc}
\hline Blend & Oil P1 / wt.\% & Oil P2 / wt.\% & Oil P3 / wt.\% & Oil P4 / wt.\% \\
\hline B1 & 39.77 & 20.68 & 9.50 & 30.05 \\
B2 & 49.93 & 10.63 & 10.05 & 29.39 \\
B3 & 39.62 & 10.80 & 30.08 & 19.50 \\
\hline
\end{tabular}

planned over five levels (with $5^{4}$ possible combinations) with Minitab ${ }^{32} 14.0$ software. For the corrosion tests and analyses by SEM and AFM, only three blends were selected (B1, B2, and B3, Table 2), considering the greater impact of crude oil P1, which had the lowest TAN, and thus acted as a diluent. ${ }^{33}$ SEM and AFM analyses were performed after the samples were immersed in the dehydrated oils and in the selected blends to identify possible corrosion processes in AISI 316 stainless and AISI 1020 carbon steels.

\section{Corrosion assays}

Samples of AISI 316 and AISI 1020 steel with a $7.83 \mathrm{~cm}^{2}$ area were washed with acetone, polished with 120- to 1220-grit sandpaper and immersed in an ultrasonic bath for 10 min with P.A. (proanalysis grade) acetone for 20 min. ${ }^{18}$ The coupons were dried with an air drier and immersed in $10 \mathrm{~mL}$ of the oils and their respective blends in closed containers. The steel samples were exposed to the oils and blends for a total of 48 days at room temperature $\left(23^{\circ} \mathrm{C}\right)$ and $1 \mathrm{~atm}$ pressure, and the conditions were static. The coupons were then removed from the oils and blends, washed with kerosene and acetone, and dried. The surface of each steel was subsequently analyzed by LM, SEM, and AFM.

\section{LM, SEM, and AFM analyses}

Triplicate SEM micrographs were collected at 1000 and 5000 times magnification using a Zeiss EVO 50 scanning electron microscope (Jena, Germany) operated at $12 \mathrm{kV}$, without metallization of the samples. The AFM images were collected using an alpha300 R confocal microscope (WITEc, Wissenschaftliche Instrument und Technologie $\mathrm{GmbH}^{\circ}$, Ulm, Germany) operated in non-contact mode (from regions selected using a light microscope, LM), with a $\mathrm{Si}_{3} \mathrm{~N}_{4}$ cantilever, a nominal constant of $42 \mathrm{~N} \mathrm{~m}^{-1}$, a resonant frequency of approximately $285 \mathrm{kHz}$, scan rates of $0.3-1.0 \mathrm{~Hz}$, and scan sizes of 2,500-10,000 nm. ${ }^{17}$ In addition to topographic images, phase and LM images were collected simultaneously. Phase images were used to estimate the physical properties of the AISI 316 steel, such as hardness, adhesion, and viscoelasticity. ${ }^{34,35}$
Surface asymmetry (Ssk), obtained from equation 1, and peak-to-peak height, given by the difference between the highest and lowest peak heights, were used to assess surface roughness. Surface asymmetry was calculated as follows:

Ssk $=\frac{1}{\mathrm{R}_{\mathrm{Q}}^{3}} \frac{1}{\mathrm{n}} \sum_{\mathrm{i}}^{\mathrm{n}}=\mathrm{Z}_{\mathrm{i}}^{3}$

where $\mathrm{Z}_{\mathrm{i}}$ is the height at position $\mathrm{i}, \mathrm{R}_{\mathrm{Q}}$ is the quadratic mean of the height deviation, and $n$ is the number of points within the image grid. In general, an Ssk of zero suggests a symmetric data distribution or an even data distribution around the mean plane, while a non-zero Ssk suggests an asymmetric distribution, where a flat surface with small peaks $(\mathrm{Ssk}>0)$ or small valleys $(\mathrm{Ssk}<0)$ is observed. ${ }^{36}$

\section{Results and Discussion}

\section{SEM analysis}

Figure 1 shows SEM images of the ASI 316 steel coupons before and after exposure to crude oils (P1, P2, $\mathrm{P} 3$, and $\mathrm{P} 4)$ and their respective blends (B1, B2, and B3); the images provided morphological details of the steel surfaces. A resolution of $2 \mu \mathrm{m}$ was achieved, with magnifications of $1000 \times$ and $5000 \times$, which identified that all the oils altered the surfaces of the steels compared to the unexposed samples. Pitting observed on the surfaces of the oil-exposed AISI 316 steel coupons was indicative of corrosion. Pitting-type corrosion occurs when the depth of the eroded area is greater than the diameter of the same area. ${ }^{37}$ The defects formed on the surfaces of the AISI 316 steels, shown in Figure 1, presented similar degrees of corrosion from all the oils studied.

With the aim of better evaluating and distinguishing the effects of naphthenic corrosion caused by different crude oils, the AISI 1020 carbon steel, which has lower corrosion resistance, was also submitted to assays, and the results are shown in Figure 2. The corrosion process was quite different among the crude oil samples, with more severe corrosion seen on the coupons immersed in crude oils P2 and P3, whereas crude oils P1 and P4 caused less corrosion. Corrosion affected the samples in the following order of impact: $\mathrm{P} 4 \approx \mathrm{P} 3>\mathrm{P} 2>\mathrm{P} 1$ 

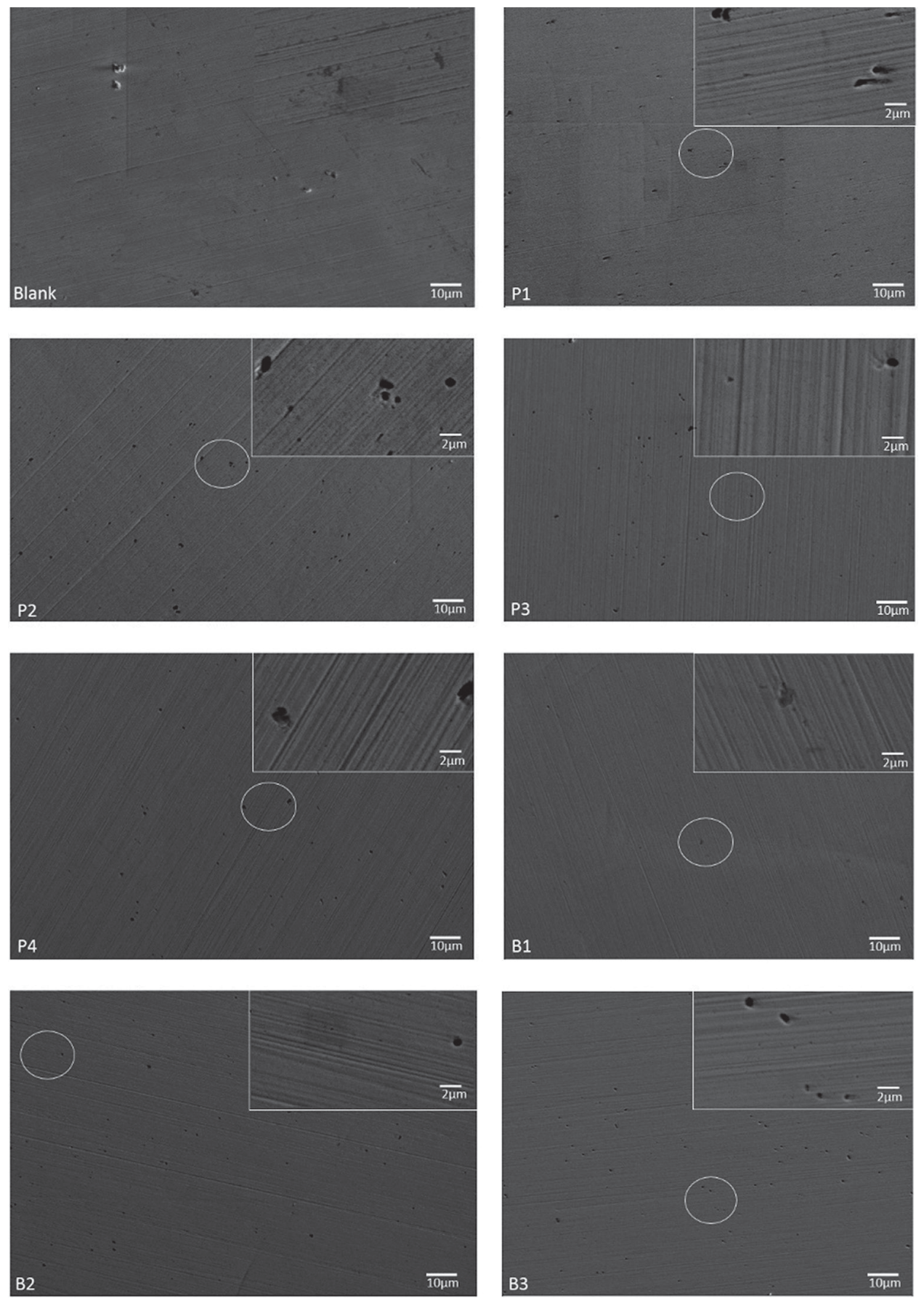

Figure 1. SEM images of the AISI 316 steel coupons before (blank) and after exposure to the crude oils (P1, P2, P3, and P4) and their blends (B1, B2, and B3). For each image, a $5000 \times$ amplification was made to the circled regions. The coupon nomenclature refers to the oil in which it was immersed.

(Figure 2). This corrosive behavior was expected, since oils P3 and P4 have comparatively high TANs and total sulfur content $\left(\mathrm{P} 3\right.$ : $\mathrm{TAN}=2.4150 \pm 0.0320 \mathrm{mg} \mathrm{KOH} \mathrm{g}^{-1}$ and total $\mathrm{S}=0.49599 \pm 0.00209 \mathrm{wt} . \%$; and P4: TAN $=1.3356 \pm 0.0136 \mathrm{mg} \mathrm{KOH} \mathrm{g}^{-1}$ and total $\mathrm{S}=0.42028 \pm 0.00040 \mathrm{wt} . \%$, Table 1).

The number of defects produced in both steels (Figures 1 and 2) from exposure to the blends was drastically lower than that produced from exposure to the crude oils. For the blends, corrosion affected the samples in the following order of impact: $\mathrm{B} 3>\mathrm{B} 2>\mathrm{B} 1$. When comparing the corrosive behavior among the two subsets of data (blends B1-B3 and oils P1-P4), the blends had, in most cases, lower TANs (1.0568-1.4620 $\mathrm{mg} \mathrm{KOH} \mathrm{g}^{-1}$ ) and total sulfur content (0.31797-0.36856 wt.\%), as shown in Table 1, proving that the blending process was efficient at reducing corrosion.

Although many studies in the literature, such as those by Huang et al..$^{38}$ and Dalmaschio et al. ${ }^{39}$ report a correlation 

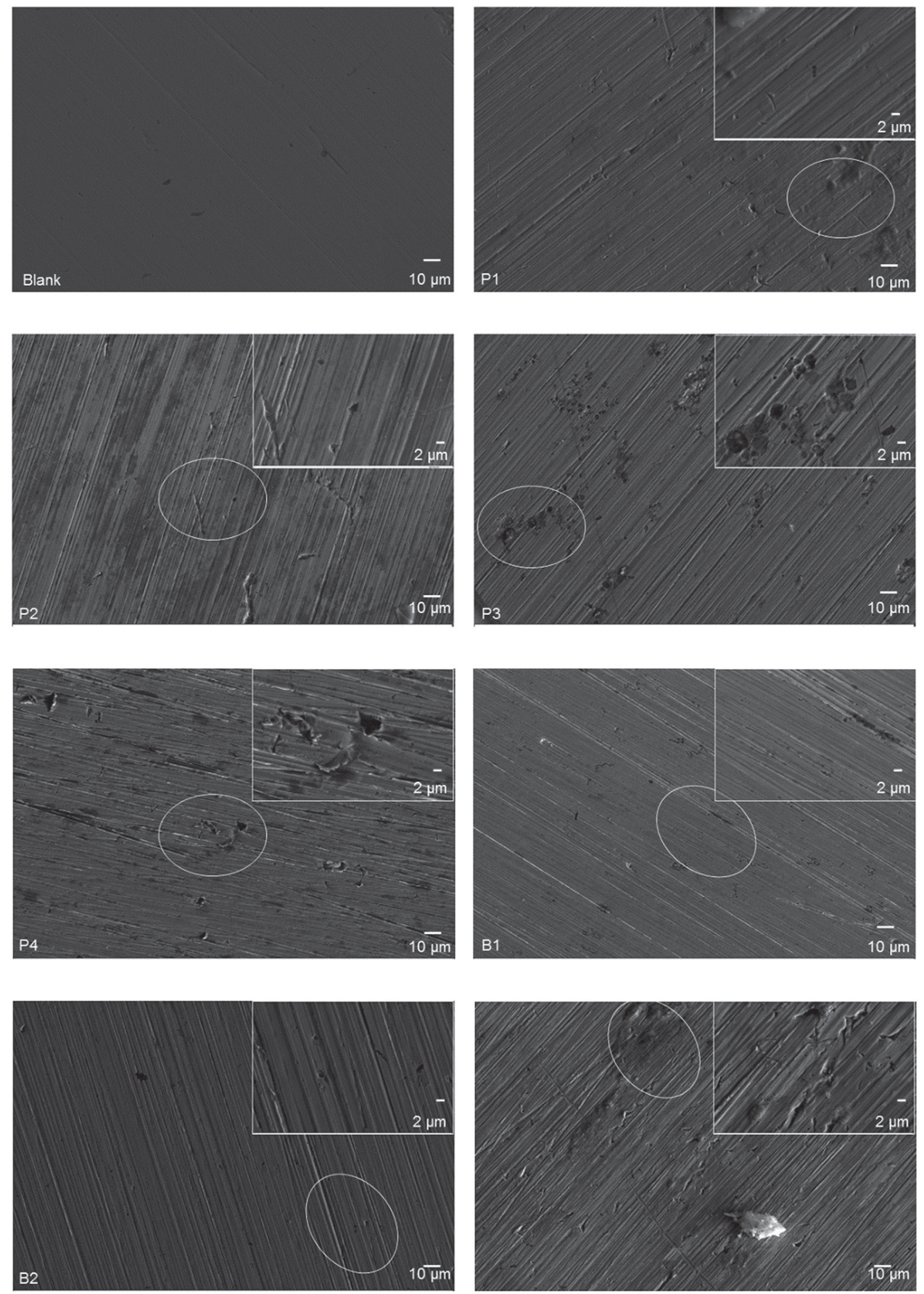

Figure 2. SEM images of the AISI 1020 steel coupons before (blank) and after exposure to the crude oils (P1, P2, P3, and P4) and their blends (B1, B2, and B3). For each image, a $5000 \times$ amplification was made to the circled regions. The coupon nomenclature refers to the oil in which it was immersed.

between the physicochemical characteristics of petroleum and corrosion, Jayaraman et $a l .{ }^{40}$ consider TAN to be a very superficial estimate for corrosion. For example, we can look at the corrosion behavior observed after exposure to oil P2. Oil P2 had the highest TAN and total S content among all the oils analyzed $(\mathrm{TAN}=2.3056 \pm 0.0013$ and total $\mathrm{S}=0.51901 \pm 0.0002 \mathrm{wt} . \%$, Table 1). However, its degree of corrosivity was similar to oil P1, as shown in Figure 2. Therefore, this behavior was due to the structure and functionality of the NAs, which can directly interfere with corrosion. ${ }^{41}$ Deyab et al. ${ }^{42}$ have proved that the molecular weight of NAs influences naphthenic corrosion. Naphthenic corrosion may also be influenced by other factors, such as the salt content and sulfur compounds, as well as the concentration of naphthenates..$^{42,43}$

Regarding the blends, the exposure of AISI 316 steel to blend B1 (Figure 1) also changed its surface. Although the corrosive impacts of blend B1 were low (Table 1), it was 
the only oil that presented alveolar-type corrosion, which is characterized by eroded areas with greater diameter than depth. ${ }^{44}$ Alveolar and pitting corrosion are types of corrosion that result from damage to the uniformity of the passive film, such as rupture, which quickly exposes the surface to attack and leads to localized corrosion. ${ }^{45,46}$ Similar corrosive attacks were seen by Freitas et al. ${ }^{47}$ who also found these two types of corrosion in samples of AISI 1020 steel exposed to crude oil and their respective distilled cuts.

The results observed and discussed here demonstrated the challenge and complexity of the study of corrosion in petroleum and petrochemical plants. Therefore, despite many research studies in this area since the discovery of naphthenic corrosion in $1920,{ }^{3}$ its occurrence has not yet been fully elucidated.

\section{LM and AFM analysis}

Figure 3 shows the LM images and AFM phase and topography images of the surface of the AISI 316 steel samples before (blank) and after exposure to different crude oils (P1-P4) and their respective blends (B1-B3) for 48 days. The LM images (Figure 3) appeared to be the same for all oils and blends tested. Although LM is widely applied in corrosion analysis, ${ }^{48-50}$ its scale often makes it difficult to see the initial phases of corrosion. The relatively noble nature of the stainless steel chosen for this study (AISI 316) also contributed to this phenomenon. ${ }^{17}$
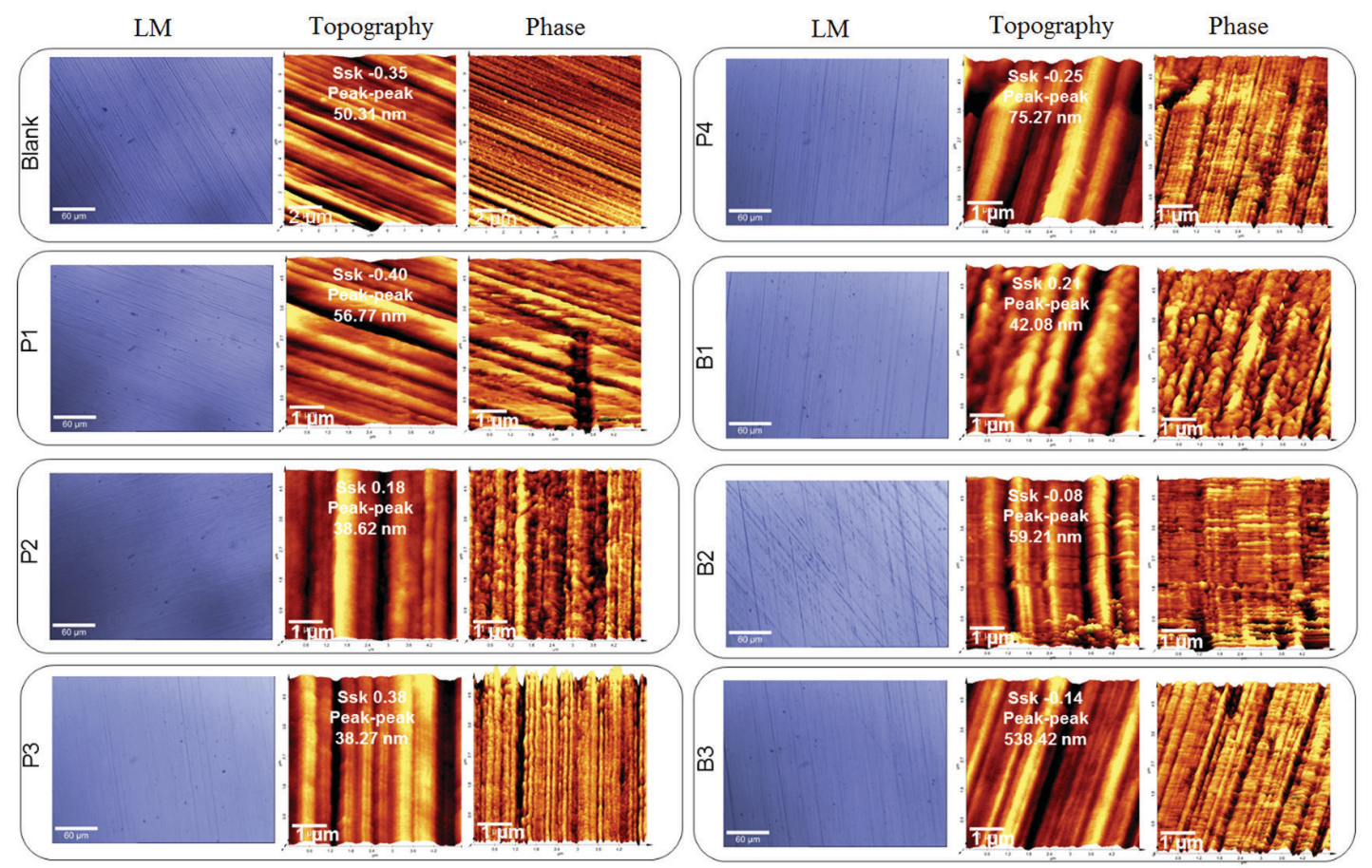

Figure 3. LM images and AFM 3D topography and phase images for the AISI 316 steel surface before (blank) and after their immersion in different crude oils (P1-P4) and their respective blends (B1-B3). The coupon nomenclature refers to the oil in which it was immersed.
Topography images of AFM for the surface of the steel (blank) showed evidence of a continuous and standardized structure, as seen in Figure 3. ${ }^{51}$ The most prominent features in the LM images were scratches produced by the polishing process, which do not cause any changes in the nanostructure but only alter the average surface ripple, ${ }^{52}$ which was measured as a peak-to-peak height of $51 \mathrm{~nm}$. The data are shown in Table 3. These values were greater than or similar to that for the unexposed blank for the samples exposed to the less corrosive oils and blends, such as P1 and $\mathrm{B} 2(\mathrm{P} 1=57 \mathrm{~nm}$ and $\mathrm{B} 2=59 \mathrm{~nm})$. Conversely, the topographic and phase profiles were remarkably altered on the samples exposed to the more corrosive oils, such as $\mathrm{P} 2-\mathrm{P} 4$, as shown in Figure 3.

Changes were observed in the phase images of the AISI 316 steel samples exposed to oil P1 and blend B1 that were not observed in the LM, SEM and topographic images (Figures 1 and 3). The phase images show both physical changes and those of an elastic nature. ${ }^{34}$ These images can be used to gauge changes in the surface of the material; thus, in this study, they were used to gauge the corrosion intensity. ${ }^{53}$

Tozzi et al. ${ }^{33}$ studied the physicochemical properties of the original oils and their respective blends $(n=68)$, noting that the kinematic viscosity, API grade, TAN and total sulfur can be reduced or improved when certain blends are produced. Similarly, the blends studied here (B1 and B2) caused less corrosion than their respective original oils,

î 
Table 3. Roughness data for the steel samples

\begin{tabular}{|c|c|c|c|c|c|}
\hline & \multirow{2}{*}{$\begin{array}{l}\text { Treatments } \\
\text { performed }\end{array}$} & \multicolumn{2}{|c|}{ AISI 316} & \multicolumn{2}{|c|}{ AISI 1020} \\
\hline & & Ssk & Peak-to-peak height / nm & Ssk & Peak-to-peak height / nm \\
\hline & blank & -0.35 & 50.61 & -1.07 & 104.35 \\
\hline \multirow{4}{*}{ Crude oil } & $\mathrm{P} 1$ & -0.40 & 56.77 & 0.30 & 345.18 \\
\hline & $\mathrm{P} 2$ & 0.18 & 38.62 & -0.52 & 576.06 \\
\hline & P3 & -0.38 & 38.37 & -0.15 & 296.82 \\
\hline & $\mathrm{P} 4$ & -0.25 & 75.27 & -0.20 & 415.42 \\
\hline \multirow{3}{*}{ Blend } & B1 & 0.21 & 42.08 & -0.18 & 290.90 \\
\hline & B2 & -0.08 & 59.21 & -0.19 & 282.18 \\
\hline & B3 & -0.13 & 38.42 & 0.22 & 286.55 \\
\hline
\end{tabular}

Ssk: surface asymmetry values.

even presenting changes in the phase images. Despite some corrosion under exposure to the blends, the AISI 316 steels exposed to blends B1 and B2 showed higher resistance to the corrosive attacks of NAs. Therefore, these mixtures reduced the effects of the corrosive processes.

Figure 4 displays the LM images and AFM 3D topography and phase images for the AISI 1020 steel coupons surface before (blank) and after immersion in crude oils (P1-P4) and their respective blends (B1-B3). In the LM images, naphthenic corrosion was seen on AISI 1020 steel in all cases and was more severe for the oils P1-P4 and blend B3. As a consequence, the topographic and phase images were drastically different, with higher

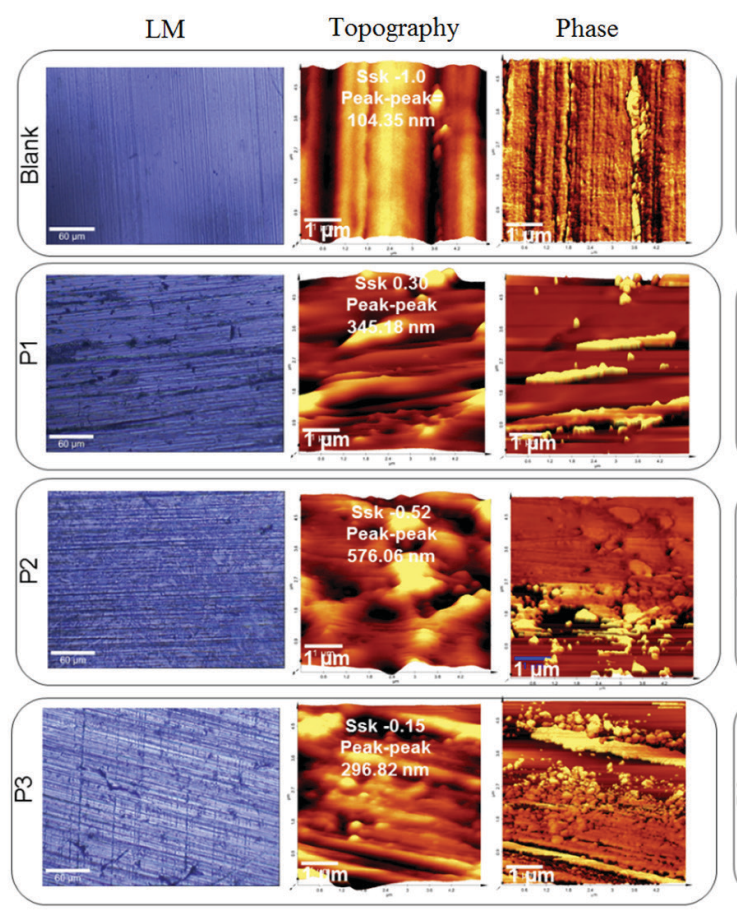

peak-to-peak heights measured primarily for the crude oil exposures $(\mathrm{P} 1-\mathrm{P} 4=297-576 \mathrm{~nm}$ and blank $=104 \mathrm{~nm})$, as seen in Table 3.

The topographic behavior obtained by the AFM analysis shown in Figures 3 and 4 was better visualized by the histograms shown in Figures 5 and S1 (SI section). The AISI 316 steel coupons exposed to oils P3 and P4 and blends B1 and B2, as shown in Figure 5, presented topographic profiles that were very similar to that of the original sample, i.e., without the presence of a high peak and with a distributed area of -30 to $30 \mu \mathrm{m}$. Conversely, the surface of the sample exposed to $\mathrm{P} 2$ was altered the most severely of all samples tested, followed by the

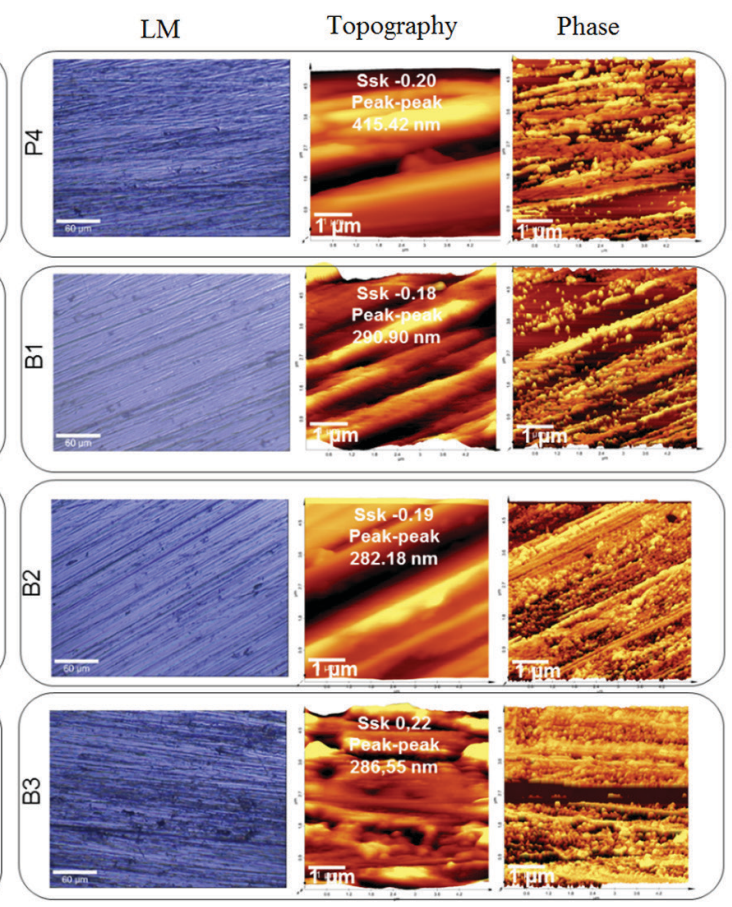

Figure 4. LM images and AFM 3D topography and phase images for the AISI 1020 steel surface before (blank) and after their immersion in different crude oils (P1-P4) and their respective blends (B1-B3). 

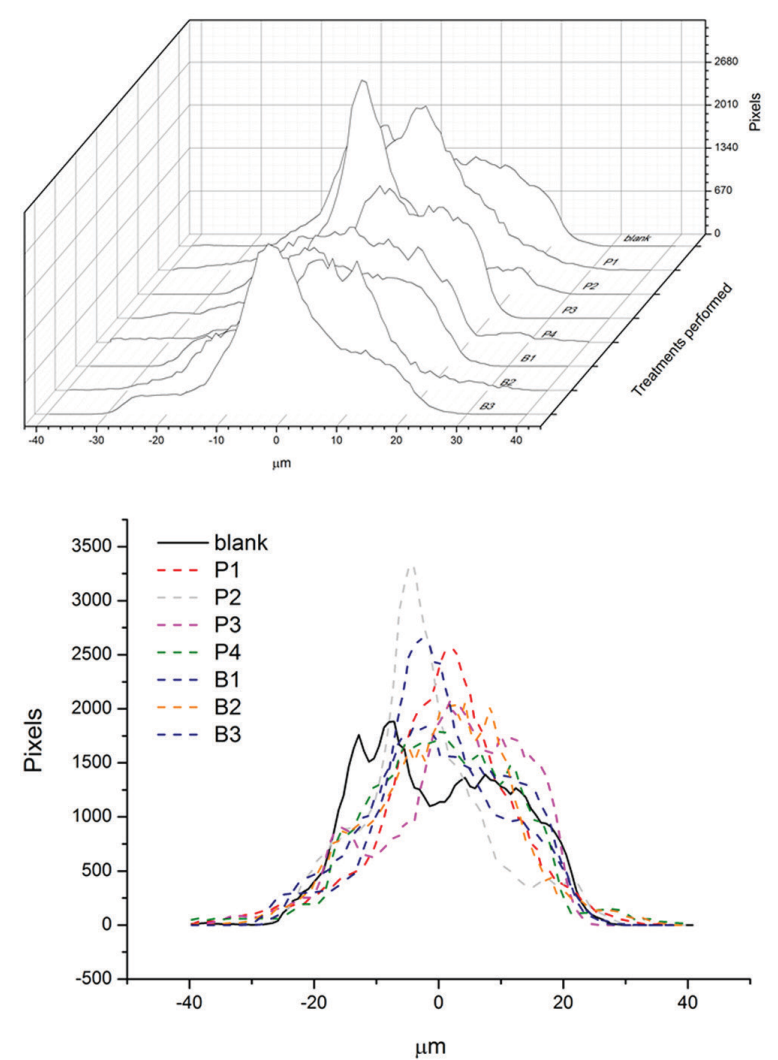

Figure 5. Histograms of the topography images obtained by AFM for AISI 316 steel before (blank) and after exposure to different crude oils and their respective blends.

sample exposed to blend B3. Consequently, a large and well-defined peak containing approximately 2000 pixels was seen.

Roughness data analysis is important in the study of the texture of a material and concerning the surface performance. ${ }^{54}$ The roughness data (Table 3 ), expressed by the parameter Ssk, suggest the symmetry or lack thereof of a sample surface. For the original coupons (blank), which had Ssks of -0.35 and -1.07 (Figures 3 and 4, respectively), an asymmetrical surface was observed with a predominance of valleys. Conversely, the AISI 316 coupon exposed to oil $\mathrm{P} 2$ experienced a change in Ssk to 0.18 , indicating the formation and predominance of peaks and an inversion in the height distribution on the steel surface. Similar behavior occurred on the coupon exposed to blend B1, with a change in Ssk to 0.21. However, the other coupons showed subtle changes in roughness.

Rios et al..$^{54}$ characterized the initial phase of corrosion of API 5L X70 steel in mineral oil that contained NAs as a function of time at room temperature, using electrochemical and microscopy techniques such as LM and AFM. The authors obtained micrographs of the metal surfaces at different immersion intervals ( $\mathrm{t}=6,12,24,60$ and $90 \mathrm{~min}$ ). Corrosion products formed rapidly, as observed after
$12 \mathrm{~min}$ of exposure, progressively increasing up to $24 \mathrm{~min} .{ }^{54}$ Therefore, as in this work, the authors saw naphthenic corrosion at temperatures much lower than those typically studied in corrosion tests $\left(\mathrm{T}>200{ }^{\circ} \mathrm{C}\right) .{ }^{18,38,47}$

\section{Conclusions}

In this work, two powerful microscopy techniques, SEM and AFM, were used to study the microstructure of the surfaces of corroded steels. SEM provided characterization of the type of naphthenic corrosion seen on the surfaces of the AISI 316 and AISI 1020 steels. AFM provided in situ analysis of the actual corrosion progression of the samples, even in the initial stages, through topography and phase images.

Naphthenic corrosion was seen on samples exposed to light and heavy oils containing a wide range of TANs ( 0.36 to $2.41 \mathrm{mg} \mathrm{KOH} \mathrm{g}^{-1}$ ). However, although some corrosion was also caused by the blends, blend B1 differed from the other oils, causing little erosion on the steel surface. The blends produced were also able to reduce the extent of corrosion compared to the original oils.

\section{Supplementary Information}

Supplementary data are available free of charge at http://jbcs.sbq.org.br as PDF file.

\section{Acknowledgments}

The authors are grateful to CENPES/PETROBRAS for financing the research (process No. 2014/00254-5). The authors thank CAPES (23038.007083/2014-40), FAPES (734/2016) and CNPq (305984/2015-2) for their financial support. The authors also thank the Núcleo de Competências em Química do Petróleo (UFES) for the corrosion assays and LabPetro for the chemical characterization of the oils.

\section{References}

1. Yéperez, O.; Fuel 2005, 84, 97.

2. Barrow, M. P.; Headley, J. V.; Peru, K. M.; Derrick, P. J.; Energy Fuels 2009, 23, 2592. DOI: 10.1021/ef800985z.

3. Piehl, R.; Mater. Perform. 1988, 27, 37.

4. ASTM D664: Standard Test Method for Acid Number of Petroleum Products by Potentiometric Titration, ASTM International, West Conshohocken, PA, 2009.

5. Hsu, C. S.; Dechert, G. J.; Robbins, W. K.; Fukuda, E. K.; Energy Fuels 1999, 14, 217.

6. Shi, Q.; Zhao, S.; Xu, Z.; Chung, K. H.; Zhang, Y.; Xu, C.; Energy Fuels 2010, 24, 4005. 
7. Tomczyk, N. A.; Winans, R. E.; Shinn, J. H.; Robinson, R. C.; Energy Fuels 2001, 15, 1498.

8. Gemelli, E.; Corrosão de Materiais Metálicos e sua Caracterização; LTC: Rio de Janeiro, 2001.

9. Gentil, V.; Corrosão, 6 ${ }^{\mathrm{a}}$ ed.; LTC: Rio de Janeiro, 2011.

10. Moreira, F. S.; Alternativas Tecnológicas para a Maximização da Produção de Olefinas Leves a partir de Petróleos Pesados; UFRJ/EQ: Rio de Janeiro, 2006.

11. Thomas, J. E.; Fundamentos de Engenharia de Petróleo, $2^{\mathrm{a}}$ ed.; Interciência, Petrobras: Rio de Janeiro, 2004.

12. Laredo, G. C.; Lópes, C. R.; Álvarez, R. E.; Cano, J. L.; Fuel 2004, 83, 1689.

13. Bryan, I.; Rice, A.; Hussey, L.; Bryan, Z.; Bobea, M.; Mita, S.; Xie, J.; Kirste, R.; Collazo, R.; Sitar, Z.; Appl. Phys. Lett. 2013, 102, 061602.

14. Park, J.; Sang-min, L.; Kang, S. L.; Lee, Y.; Lee, E. S.; J. Alloys Compd. 2015, 619, 205.

15. Johnston, S. L.; Voordouw, G.; Environ. Sci. Technol. 2012, 46, 9183.

16. Dias, H. P.; Dixini, P. V.; Almeida, L. C. P.; Vanini, G.; Castro, E. V. R.; Aquije, G. M. F. V.; Gomes, A. O.; Moura, R. R.; Lacerda, V. J.; Vaz, B. G.; Romão, W.; Fuel 2015, 139, 328.

17. Marin, E.; Lanzutti, A.; Lekka, M.; Guzman, L.; Ensinger, W.; Fedrizzi, L.; Surf. Coat. Technol. 2011, 11, 84.

18. Dias, H. P.; Pereira, T. M. C.; Vanini, G.; Dixini, P. V.; Celante, V. G.; Castro, E. V. R.; Vaz, B. G.; Fleming, F. P.; Gomes, A. O.; Aquije, G. M. F. V.; Romão, W.; Fuel 2014, 126, 85.

19. Uluanov, P. G.; Usachov, D. Y.; Fedorov, A. V.; Bondarenko, A. S.; Senkovskiy, B. V.; Vyenko, O. F.; Pushko, S. V.; Balizhd, K. S.; Maltcev, A. A.; Borygina, K. I.; Dobrotvorskii, A. M.; Adamchuk, V. K.; Appl. Surf. Sci. 2013, 267, 216.

20. Zhang, F.; Pan, J.; Martin, P. C.; Electrochim. Acta 2011, 56, 1636.

21. Fang, H. H. P.; Chan, K. Y.; Xu, L. C.; J. Microbiol. Methods 2000, 40, 89 .

22. Beech, I. B.; Smith, J. R.; Steele, A. A.; Penegar, I.; Campbell, S. A.; Colloids Surf., B 2002, 23, 231.

23. Joergensen, L.; Klösgen, B.; Simonsen, A. C.; Borch, J.; Hagesaether, E.; Int. J. Pharm. 2011, 411, 162.

24. ASTM D5854: Standard Practice for Mixing and Handling of Liquid Samples of Petroleum and Petroleum Products, ASTM International, West Conshohocken, PA, 2015.

25. Sad, C. M. S.; Santana, I. L.; Morigaki, M. K.; Medeiros, E. F.; Castro, E. V. R.; Santos, M. F. P.; Filgueiras, P. R.; Fuel 2015, 150, 705.

26. ASTM D4377: Standard Test Method for Water in Crude Oils by Potentiometric Karl Fischer Titration, Reapproved 2011, ASTM International, West Conshohocken, PA, 2000.

27. Barbosa, L. L.; Sad, C. M. S. S.; Morgan, V. G.; Santos, M. F. P.; Castro, E. V. R.; Energy Fuels 2013, 27, 6560.
28. ASTM D1250: Standard Guide for Petroleum Measurement Tables, ASTM International, West Conshohocken, PA, 2008.

29. ASTM D4052: Standard Test Method for Density, Relative Density, and API Gravity of Liquids by Digital Density Meter, ASTM International, West Conshohocken, PA, 2016.

30. ASTM D7042: Standard Test Method for Kinematics Viscosity in Crude Oil, ASTM International, West Conshohocken, PA, 2004.

31. ASTM D4294: Standard Test Method for Sulfur in Petroleum and Petroleum Products by Energy Dispersive X-Ray Fluorescence Spectrometry, ASTM International, West Conshohocken, PA, 2008.

32. Minitab Statistical Software, Release 14, Minitab Inc., State College, PA, 2003.

33. Tozzi, F. C.; Sad, C. M. S.; Bassane, J. F. P.; dos Santos, F. D.; Silva, M.; Filgueiras, P. R.; Dias, H. P.; Romão, W.; Castro, E. V. R.; Lacerda, V. J.; Fuel 2015, 159, 607.

34. Batina, N.; Manzano, M. J. C.; Andersen, S. I.; Lira, G. C.; Energy Fuels 2003, 17, 532.

35. Butt, H. J.; Cappella, B.; Kappl, M.; Surf. Sci. Rep. 2005, 59, 1.

36. Fornós, J. J.; Pujol, L. L. G.; Cifre, J.; Hierro, F.; Acta Carsologica 2011, 40, 275.

37. Cui, U. I. N.; Qiao, L. J.; Choivelli, S.; Br. Corros. J. 2013, 35, 210.

38. Huang, B. S.; Yin, W. F.; Sang, D. H.; Jiang, Z. Y.; Appl. Surf. Sci. 2012, 259, 664.

39. Dalmaschio, G. P.; Malacarne, M. M.; Almeida, V. M. D. L.; Pereira, T. M. C.; Gomes, A. O.; de Castro, E. V. R.; Greco, S. J.; Vaz, B. G.; Romão, W.; Fuel 2014, 115, 190.

40. Jayaraman, A.; Singh, H.; Lefebvre, Y.; Rev. Inst. Fr. Pet. 1986, $41,265$.

41. Qu, D. R.; Zheng, Y.-G.; Jiang, X.; Ke, W.; Anti-Corros. Methods Mater. 2007, 54, 211.

42. Deyab, M. A.; Abo Dief, H. Á.; Eissa, E. A.; Taman, A. R.; Electrochim. Acta 2007, 52, 8105.

43. Slavcheva, E.; Shone, B.; Turnbull, A.; Corros. J. 1999, 34, 125.

44. Purcell, J. M.; Merdrignac, I.; Rodgers, R. P.; Marshall, A. G.; Gauthier, T.; Guibard, I.; Energy Fuels 2010, 24, 2257.

45. Hashimoto, M.; Miyajima, S.; Murata, S. T.; Corros. Sci. 1992 , 33,885 .

46. Dong, H. Z.; Shi, W.; Guo, X. P.; Corros. Sci. 2011, 53, 1322.

47. Freitas, S.; Malacarne, M. M.; Romão, W.; Dalmaschio, G. P.; Castro, E. V. R.; Celante, V. G.; Freitas, M. B. J. G.; Fuel 2013, 104, 656.

48. Boniatti, R.; Bandeira, A. L.; Crespi, A. E.; Aguzzoli, C.; Baumvol, I. J. R.; Figueroa, C. A.; Appl. Surf. Sci. 2013, 280, 156.

49. Liu, J.; Shi, Q.; Luan, H.; Yan, W.; Sha, W.; Wang, W.; Shan, Y.; Yang, K.; Oxid. Met. 2015, 84, 383.

50. Szkodo, M.; J. Mater. Process. Technol. 2005, 162, 410. 
51. Pompeo, G.; Girasole, M.; Longo, G.; Cricente, A.; Bailo, D.; Ronci, F.; Maras, A.; Serracino, M.; Moretti, P.; J. Microsc. 2008, 230, 218.

52. Osorio, E.; Toledano, M.; Silveira, B. L.; Osorio, R.; J. Dent. 2010, 38, 118.
53. Goméz-Pachón, E. Y.; Sánchez-Arévalo, F. M.; Sabina, F. J.; Maciel-Cerda, A.; Campos, R. M.; Batina, N.; Morales-Reyes, I.; Vera-Graziano, R.; J. Mater. Sci. 2013, 48, 8308.

54. Rios, E. C.; Oliveira, A. L.; Zimer, A. M.; Freitas, R. G.; Matos, R.; Pereira, E. C.; Mascaro, L. H.; Fuel 2016, 184, 648.

Submitted: April 27, 2018

Published online: May 25, 2018 